\title{
ANTIBACTERIAL ACTIVITY OF “ANASTATICA HIEROCHUNTICA L." AGAINST SOME BACTERIAL STRAINS RESPONSIBLE FOR WOMEN'S URO-GENITAL INFECTION
}

\author{
ELHASSAN BENYAGOUB ${ }^{1 *}$, NOURIA NABBOU ${ }^{2}$, DALILA RAZNI ${ }^{1}$, SNOUSSI MOGHTET ${ }^{3}$
}

${ }^{1}$ Department of Biology, Faculty of Life and Natural Sciences, Tahri Mohammed University of Bechar (08000), Bechar, Algeria. ${ }^{2}$ Department of Chemistry, Faculty of Exact Sciences, Tahri Mohammed University of Bechar (08000), Bechar, Algeria. ${ }^{3}$ Department of Life and Natural Sciences, Institute of sciences, Nour Bachir University Center of El Bayadh, (32000), El Bayadh, Algeria. E-mail: benyagoubelhassan@gmail.com

Received: 06 December 2017, Revised and Accepted: 06 April 2018

\section{ABSTRACT}

Objective: The purpose of this work is to study the biological activity of Anastatica hierochuntica L., against nine bacterial strains responsible for women's uro-genital infection (UGI).

Methods: The plant was collected from Tindouf region (far southwest Algeria). In this study, we performed an evaluation of antibacterial activity of three macerates of two vegetative parts (seeds and stems) by two methods (disc and wells diffusion methods), with a description of the antibiotic resistance profile of isolated bacterial strains by antibiogram method.

Results: According to the results, the antibiotic resistance profile of the tested bacterial strains showed an increased resistance against several antibiotics families. The evaluation of the antibacterial potential of macerates showed that methanolic and aqueous macerates of the seeds were more active against Gram-positive bacteria compared to Gram-negative bacteria.

Conclusion: The preliminary results of this study allowed us to predict that natural substances in the plant can be considered as an important source to possess compounds with significant antibacterial properties and thus suggest their application in the pharmaceutical industry.

Keywords: Anastatica hierochuntica L., Antibacterial activity, Women's urogenital infection, antibiotic resistance profile, Tindouf(Algeria).

(C) 2018 The Authors. Published by Innovare Academic Sciences Pvt Ltd. This is an open access article under the CC BY license (http://creativecommons. org/licenses/by/4. 0/) DOI: http://dx.doi.org/10.22159/ajpcr.2018.v11i7.22952

\section{INTRODUCTION}

Urinary infection is a set of pathologies whose common denominator is the urinary tract infection (UTI) or its annex for which the urine culture is positive [1]. The UTI is, after respiratory infections, the second leading causes for consultation.

In the United States, bacterial cystitis in women generates nearly 7 million annual consultations and 1 million visits to emergency services and thus leads to 1,00,000 hospitalization. Financially, the community's annual cost of an acquired UTI is significant, about 1.6 billion dollars (USD). Today, it represents 6-8 \% approximately 8,00,000 cases reported each year in France [2,3].

For this purpose, the UTI has been extensively studied because of its frequency and severity etiological or progressive, motivating most often antibiotic prescriptions without knowing the causal germ or their antibiotics profile [4]. However, with the emergence of resistant urinary pathogens observed in some community and hospital settings, new young researchers go back to nature, to search for bioactive molecules of vegetable origin powerful against these pathogens.

Plant biodiversity of the Sahara is characterized by the presence of medicinal plants having a great therapeutic potential against several diseases. For a long time, natural remedies, and especially, medicinal plants were the principal recourse of medicine for our grandparents, despite the significant development of the pharmaceutical industry that allowed modern medicine to treat a large number of often fatal diseases $[5,6]$.

The species of Anastatica hierochuntica L. from crucifiers are an important dicotyledonous plant family, and it is known for its therapeutic properties as a hepatoprotective plant, hypoglycemic, and diuretic. It is used in traditional medicine for uterine bleeding, to facilitate the expulsion of dead fetus, and to treat gastrointestinal disorders, depression, high blood pressure, indigestion, headache, fever, malaria, epilepsy, heart disease, and infertility [7].

The main interest here is to highlight the antibacterial activity of its excerpts, namely the methanolic, aqueous, and etheric macerates, against nine bacterial strains responsible for women's uro-genital infection .

\section{METHODS}

This study was conducted at Dr. H. KADI's pedagogical laboratory (Tahri Mohammed University of Bechar -Algeria), after preparing the plant as follows:

\section{Collection and extraction of plant materials}

The plant studied was collected 2 times after being identified during the months of February-March for 2016 and 2017 in the far southwest Algeria - Tindouf region (Algerian-Moroccan border) (Fig. 1). The dried plant was put into clean bags.

The aqueous, methanolic, and etheric macerates of the plant studied were obtained by maceration with the following method: A test sample $10 \mathrm{~g}$ of the dried plant was mixed with $100 \mathrm{ml}$ of distilled water. The mixture is stirred for $24 \mathrm{~h}$. After filtration through a filter paper, the filtrate is evaporated by steam evaporation in rotary flask evaporator (Buchi Rotavapor R-210, Switzerland), till it dried under reduced pressure at $100^{\circ} \mathrm{C}$ to obtain the aqueous macerates residue.

However, for the methanol and etheric macerates, a test sample $5 \mathrm{~g}$ of dried plant was mixed with $85 \mathrm{ml}$ of methanol and diethyl ether, 
respectively. The mixture is stirred for $24 \mathrm{~h}$. After filtration, the filtrate is too evaporated, till it dried under reduced pressure at 65 and $35^{\circ} \mathrm{C}$, respectively [9].

\section{Bacterial strains}

The evaluation of the antibacterial activity of extracts of the plant studied was conducted in accordance with official methods. However, the tested microorganisms were isolated from genital and urinary samples of women by cytobacteriological examination performed at the private medical analysis laboratory in Bechar (Algeria). The isolated strains have experienced: first, identification by macroscopic examination of colonies on nutrient agar (phenotypic characteristics) and microscopic observation in the fresh state and after differential Gram-stain; and second, identification of biochemical characteristics through classical and miniaturized gallery (IMVIC, staphylocoagulase test, and oxidase and catalase test, API 20E and API Staph "BioMerieux, France"). The isolated and identified microorganisms were a total of nine bacterial strains distributed as follows: Five strains of Escherichia coli, Staphylococcus aureus, Citrobacter freundii, Proteus mirabilis, Pseudomonas aeruginosa, and Enterococcus faecalis. Pure cultures were maintained and stored at $+4^{\circ} \mathrm{C}$ until use.

\section{Antibacterial susceptibility test}

The colonies which were isolated from young cultures on nutrient agar medium (Fluka, India) incubated at $37^{\circ} \mathrm{C}$ for $18-24 \mathrm{~h}$ are transferred into tubes containing sterile physiological saline water $(0.9 \% \mathrm{NaCl})$. The number of cells in $1 \mathrm{ml}$ of suspension for inoculation measured by the McFarland nephelometer was $1 \times 10^{7} \mathrm{cfu} / \mathrm{ml}$. Then, the bacterial suspension, prepared beforehand, was seeded using a sterile swab over the entire surface of a Mueller-Hinton (MH) agar medium (HiMedia, India) by tight streaks.

The study of antibiotic resistance profile of isolated strains toward antibiotics was performed by the diffusion method on MH agar medium using loaded discs of antibiotics as recommended by the National Committee for Clinical Laboratory Standards [10]. These results were interpreted according to the reference table prepared by Antibiogram Committee of the French Society for Microbiology [11].

The used antibiotic discs for disc diffusion method were as follows: first, cefoxitin, cefazolin, chloramphenicol, amoxicillin-clavulanic acid, ampicillin, gentamicin, ofloxacin, imipenem, and cefotaxime for E. coli, C. freundii, and P. mirabilis; second, penicillin, oxacillin, vancomycin, fosfomycin, fusidic acid, erythromycin, amikacin, and gentamicin for S. aureus; third, ofloxacin, tobramycin, imipenem, rifampin, ticarcillin, fosfomycin, amikacin, and cefotaxime for $P$. aeruginosa; and finally, vancomycin, tetracycline, gentamicin, ampicillin, and erythromycin for $E$. faecalis

The antibacterial activity of the extracts was determined by the disc diffusion method and well diffusion method on agar medium $[12,13]$. The first method consists of substituting the antibiotic discs by other confined discs from Whatman paper that are impregnated with the extract.

Each inoculated Petri dish contains the impregnated discs with dimethyl sulphoxide (DMSO), methanol and diethyl ether which they used as a control. Finally, the dishes were incubated at $37^{\circ} \mathrm{C}$ for $24 \mathrm{~h}$.

The second method which we used to confirm the action of the tested extracts was described by Vlietink and Vanden Berghe [14]. This method consists of cutting a circular hole in the MH agar medium, and thus, each extract solution was poured with a volume of $10 \mu \mathrm{l}$ in the well.

The radial diffusion of extract gives a circular inhibition zone to the agar surface seeded with the bacterial suspension by streaked swabbing. Inhibition zones were measured and expressed in $\mathrm{mm}$ and in percentage $(\%)$ in relation to the Petri dish diameter

\section{Statistical analysis}

Results were expressed as mean values and standard deviation. Statistical analyses were determined using Excel software program.

\section{RESULTS}

The antimicrobial resistance profile results of the bacterial strains against antibiotics performed by the diffusion method on $\mathrm{MH}$ agar medium are reported in Table $1 \mathrm{a}$ and $\mathrm{b}$.

The antibiotic resistance profile of the tested bacterial strains showed an increased resistance to ampicillin, trimethoprim-sulfamethoxazole, cefazolin, cefoxitin, and ofloxacin for E. coli, C. freundii, and P. mirabilis, while $S$. aureus and $E$. faecalis showed resistance to vancomycin, clindamycin, erythromycin, penicillin, and oxacillin. However, P. aeruginosa strain was sensitive to tested antibiotics (Fig. 2).

The results of antibacterial test performed by the agar diffusion method which were evaluated by measuring the inhibition zones around the discs are shown in Table $2 \mathrm{a}$ and $\mathrm{b}$.

The results indicate that the aqueous and methanolic macerates of the seeds showed an antibacterial effect on six strains including two Gram-positive and four Gram-negative bacteria (P. mirabilis, E. faecalis, S. aureus, and E. coli 2, 4, and 5). However, no inhibition was observed on E. coli 1, E.coli 3, P. aeruginosa, and $C$. freundii. The etheric macerate was found ineffective against the tested strains until $100 \mathrm{mg} / \mathrm{ml}$. For stem macerates, the results indicate that the methanolic macerate presented an antibacterial effect only on $E$. coli 5 strain at a concentration of $235 \mathrm{mg} / \mathrm{ml}$ with an inhibition zone of $11 \pm 0.8 \mathrm{~mm}$

However, the aqueous and etheric macerates did not show any antibacterial effect on all tested strains. Based on our results, it was noted that seed macerates were more effective than stem macerates. The results of the antibacterial test performed by the agar diffusion

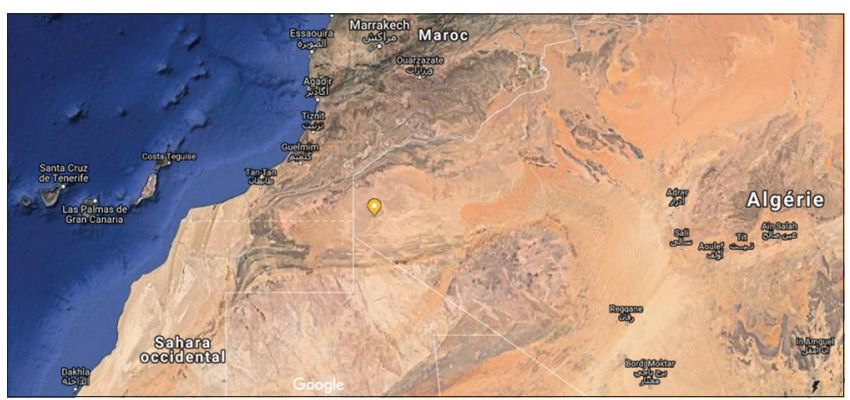

Fig. 1: Collection site of Anastatica hierochuntica L. in Tindouf, Algeria (yellow spot) [8]

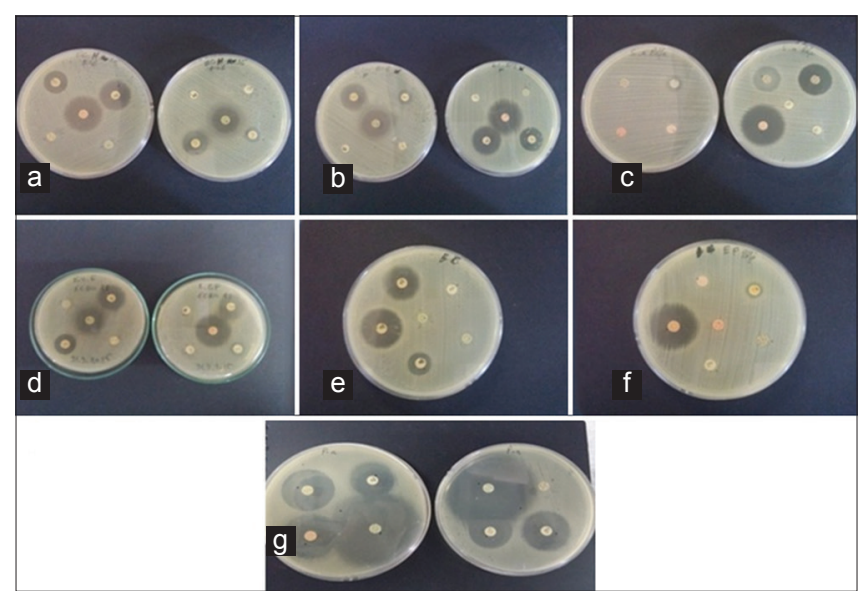

Fig. 2: Antibiogram tests of the uropathogenic strains on Mueller Hinton agar. (a) Escherichia coli 1, (b) E. coli 3, (c) Staphylococcus aureus, (d) E. coli 5, (e) Proteus mirabilis, (f) Enterococcus faecalis, (g) Pseudomonas aeruginosa 
Table 1a: Diameter values of inhibitory zones and inhibition percentages (I\%) of antibiotics against the bacterial strains responsible for women's UGI.

\begin{tabular}{|c|c|c|c|c|c|c|c|c|c|c|c|c|c|c|c|}
\hline \multirow[t]{3}{*}{ ATB } & \multicolumn{15}{|c|}{ Bacterial strains } \\
\hline & \multicolumn{3}{|c|}{ P. aeruginosa } & \multicolumn{3}{|c|}{ E. faecalis } & \multicolumn{3}{|c|}{ P. mirabilis } & \multicolumn{3}{|c|}{ S. aureus } & \multicolumn{3}{|c|}{ C. freundii } \\
\hline & D & I (\%) & $\mathbf{P}_{{ }_{\mathrm{ATB}}}$ & D & I (\%) & $\mathbf{P}_{\text {ATB }}$ & D & I (\%) & $\mathbf{P}_{\text {ATB }}$ & D & I (\%) & $\mathbf{P}_{{ }_{\mathrm{ATB}}}$ & D & I (\%) & $\mathbf{P}_{\mathbf{A T B}_{\mathrm{AT}}}$ \\
\hline Fosfomycin & - & - & - & - & - & - & - & - & - & 9 & 10 & $\mathrm{R}$ & - & - & - \\
\hline Chloramphenicol & - & - & - & - & - & - & - & - & - & - & - & - & 35 & 38.88 & $\mathrm{~S}$ \\
\hline Cefazolin & - & - & - & - & - & - & 6 & 6.66 & $\mathrm{R}$ & - & - & - & 6 & 6.66 & $\mathrm{R}$ \\
\hline $\begin{array}{l}\text { Amoxicillin-clavulanic } \\
\text { acid }\end{array}$ & - & - & - & - & - & - & 25 & 27.77 & S & - & - & - & 36 & 40 & $\mathrm{~S}$ \\
\hline Oxacillin & - & - & - & - & - & - & - & - & - & 6 & 6.66 & $\mathrm{R}$ & - & - & - \\
\hline Penicillin & - & - & - & - & - & - & 6 & 6.66 & $\mathrm{R}$ & 6 & 6.66 & $\mathrm{R}$ & - & - & - \\
\hline Vancomycin & - & - & - & 6 & 6.66 & $\mathrm{R}$ & - & - & - & 6 & 6.66 & $\mathrm{R}$ & - & - & - \\
\hline Gentamicin & 30 & 33.33 & $\mathrm{~S}$ & 26 & 28.88 & S & - & - & - & 25 & 27.77 & S & 35 & 38.88 & $\mathrm{~S}$ \\
\hline Erythromycin & - & - & - & 6 & 6.66 & $\mathrm{R}$ & - & - & - & 6 & 6.66 & $\mathrm{R}$ & - & - & - \\
\hline Tetracycline & - & - & - & 6 & 6.66 & $\mathrm{R}$ & - & - & - & - & - & - & - & - & - \\
\hline Clindamycin & - & - & - & - & - & - & - & - & - & 6 & 6.66 & $\mathrm{R}$ & - & - & - \\
\hline Cefoxitin & - & - & - & - & - & - & 20 & 22.22 & S & - & - & - & 6 & 6.66 & $\mathrm{R}$ \\
\hline Ofloxacin & 30 & 33.33 & $\mathrm{~S}$ & - & - & - & - & - & - & - & - & - & 21 & 23.33 & $\mathrm{~S}$ \\
\hline Imipenem & 48 & 53.33 & $\mathrm{~S}$ & - & - & - & - & - & - & - & - & - & 28 & 31.11 & $\mathrm{~S}$ \\
\hline Ceftazidime & - & - & - & - & - & - & 15 & 16.66 & S & - & - & - & - & - & - \\
\hline Amikacin & 27 & 30 & $\mathrm{~S}$ & - & - & - & - & - & - & 21 & 23.33 & S & - & - & - \\
\hline Tobramycin & 25 & 27.77 & $\mathrm{~S}$ & - & - & - & - & - & - & - & - & - & - & - & - \\
\hline Ampicillin & - & - & - & - & - & - & - & - & - & - & - & - & 30 & 33.33 & $\mathrm{~S}$ \\
\hline Fusidic acid & - & - & - & - & - & - & - & - & - & 6 & 6.66 & $\mathrm{R}$ & - & - & - \\
\hline Ticarcillin & 50 & 55.55 & $\mathrm{~S}$ & - & - & - & - & - & - & - & - & - & - & - & - \\
\hline
\end{tabular}

UGI: Urogenital infection, D: Diameter of inhibition zones (mm), I (\%): Inhibition percentage, P. ATB: Antibiotic resistance profile, S: Sensitive, R: Resistant, I: Intermediate, ATB: Antibiotics, E. coli: Escherichia coli, P. aeruginosa: Pseudomonas aeruginosa, E. faecalis: Enterococcus faecalis, P. mirabilis: Proteus mirabilis, S. aureus: Staphylococcus aureus, C. freundii: Citrobacter freundii

Table 1b: Diameter values of inhibitory zones and inhibition percentages (I\%) of antibiotics against the bacterial strains responsible for women's UGI

\begin{tabular}{|c|c|c|c|c|c|c|c|c|c|c|c|c|c|c|c|}
\hline \multirow[t]{3}{*}{ ATB } & \multicolumn{15}{|c|}{ Bacterial strains } \\
\hline & \multicolumn{3}{|c|}{ E. coli 1} & \multicolumn{3}{|c|}{ E. coli 2} & \multicolumn{3}{|c|}{ E. coli 3} & \multicolumn{3}{|c|}{ E. coli 4} & \multicolumn{3}{|c|}{ E.coli 5} \\
\hline & D & I (\%) & $\mathbf{P}_{{ }_{\mathrm{ATB}}}$ & D & I (\%) & $\mathbf{P}_{{ }_{\mathrm{ATB}}}$ & D & I (\%) & $\mathbf{P}_{\mathrm{ATB}}$ & D & I (\%) & $\mathbf{P}_{\text {ATB }}$ & D & I (\%) & $\mathbf{P}_{{ }_{\mathrm{ATB}}}$ \\
\hline Chloramphenicol & 10 & 11.11 & $\mathrm{~S}$ & 17 & 18.88 & $\mathrm{~S}$ & 19 & 21.11 & $\mathrm{~S}$ & 17 & 18.88 & $\mathrm{~S}$ & 31 & 34.44 & $\mathrm{~S}$ \\
\hline Cefazolin & 6 & 6.66 & $\mathrm{R}$ & 6 & 6.66 & $\mathrm{R}$ & 6 & 6.66 & $\mathrm{R}$ & 6 & 6.66 & $\mathrm{R}$ & 6 & 6.66 & $\mathrm{R}$ \\
\hline $\begin{array}{l}\text { Amoxicillin-clavulanic } \\
\text { acid }\end{array}$ & 6 & 6.66 & $\mathrm{R}$ & 6 & 6.66 & $\mathrm{R}$ & 6 & 6.66 & $\mathrm{R}$ & 6 & 6.66 & $\mathrm{R}$ & 30 & 33.33 & S \\
\hline Gentamicin & 28 & 31.11 & $\mathrm{~S}$ & 26 & 28.88 & $\mathrm{~S}$ & 27 & 30 & $\mathrm{~S}$ & 25 & 27.77 & $\mathrm{~S}$ & 28 & 31.11 & $\mathrm{~S}$ \\
\hline Ampicillin & 6 & 6.66 & $\mathrm{R}$ & 6 & 6.66 & $\mathrm{R}$ & 6 & 6.66 & $\mathrm{R}$ & 6 & 6.66 & $\mathrm{R}$ & 6 & 6.66 & $\mathrm{R}$ \\
\hline Cefoxitin & 6 & 6.66 & $\mathrm{R}$ & 20 & 22.22 & $\mathrm{~S}$ & 22 & 24.44 & $\mathrm{~S}$ & 21 & 23.33 & $\mathrm{~S}$ & 6 & 6.66 & $\mathrm{R}$ \\
\hline Cefotaxime & 15 & 16.66 & I & 21 & 23.33 & $\mathrm{~S}$ & 21 & 23.33 & S & 18 & 20 & $\mathrm{~S}$ & 22 & 24.44 & I \\
\hline Ofloxacin & 6 & 6.66 & $\mathrm{R}$ & 12 & 13.33 & $\mathrm{~S}$ & 12 & 13.33 & S & 11 & 12.22 & $\mathrm{~S}$ & 35 & 38.88 & S \\
\hline Imipenem & 31 & 34.44 & $\mathrm{~S}$ & 22 & 24.44 & $\mathrm{~S}$ & 21 & 23.33 & $\mathrm{~S}$ & 18 & 20 & $\mathrm{~S}$ & 35 & 38.88 & S \\
\hline
\end{tabular}

UGI: Urogenital infection, D: Diameter of inhibition zones (mm), I (\%): Inhibition percentage, P. ${ }_{\text {ATB }}$ : Antibiotic resistance profile, S: Sensitive, R: Resistant, I: Intermediate, ATB: Antibiotics, E. coli: Escherichia coli, P. aeruginosa: Pseudomonas aeruginosa, E. faecalis: Enterococcus faecalis, P. mirabilis: Proteus mirabilis, S. aureus: Staphylococcus aureus, C. freundii: Citrobacter freundii

method which were evaluated by measuring the inhibition zones around the discs are shown in Figs. 3 and 4.

\section{DISCUSSION}

The plants have traditionally provided a source of hope for novel drug compounds, and the use of plant extracts with known antimicrobial properties can be of great significance for therapeutic treatment [15].

Most epidemiological studies have shown that the incidence of UGI is higher among women [16] which were revealed by Benyagoub et al. [17] with a female dominance. This is directly related to the anatomical structure of the female urinary apparatus. For this reason, we have isolated urinary pathogens from the female population. Knowing that some work namely Adjei et Opoku; Aroor et al., $[18,19]$ which they found in two studies carried out in Ghana and India respectively a maledominance for UTI

The antibiotic resistance results were in agreement with the study of Benyagoub et al. [17], about the emergence of antibiotic resistance of microorganisms responsible for urinary tract infections (UTI) in Bechar (Algeria) where a total of 145 strains were isolated and have experienced an antibiogram test.

Antibiotic resistance was relatively high for specific molecules, in particular, beta-lactams (penicillin, oxacillin, ampicillin, and amoxicillin-clavulanic acid), sulfamides (cotrimoxazole), and macrolides (erythromycin) for E. coli and S. aureus. The carbapenems, third-generation cephalosporins (C3G), aminoglycoside antibiotics 


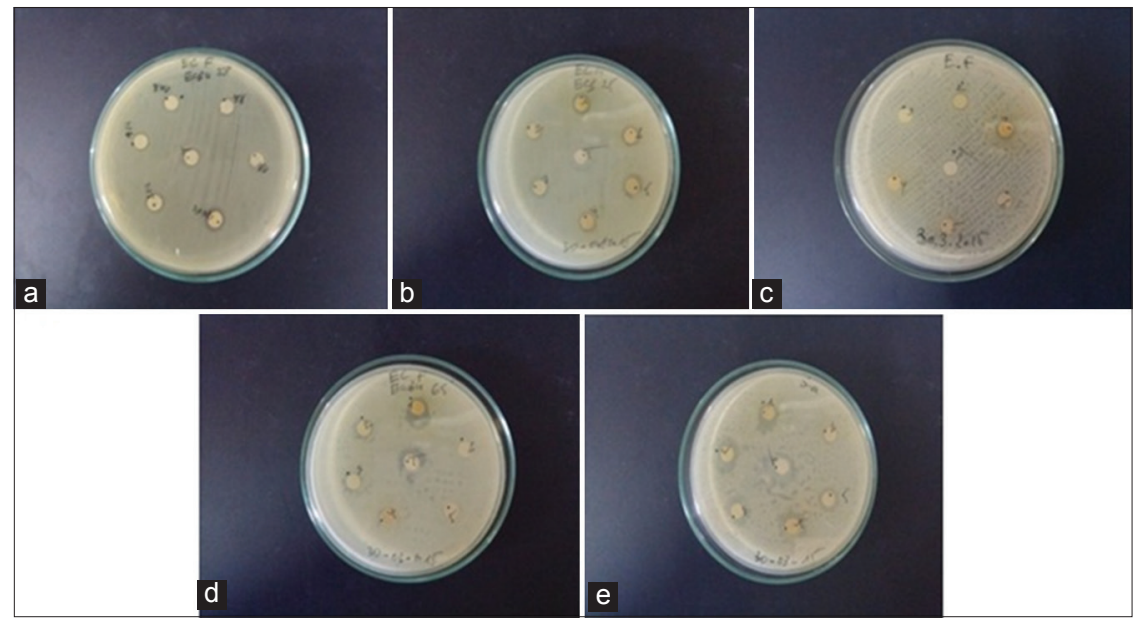

Fig. 3: Photographic illustration of the Anastatica hierochuntica macerates' disc diffusion tests against uropathogenic strains on MuellerHinton agar medium. (a): Escherichia coli 3, (b): E. coli 4, (c): Enterococcus faecalis, (d): E. coli 2, (e): Staphylococcus aureus

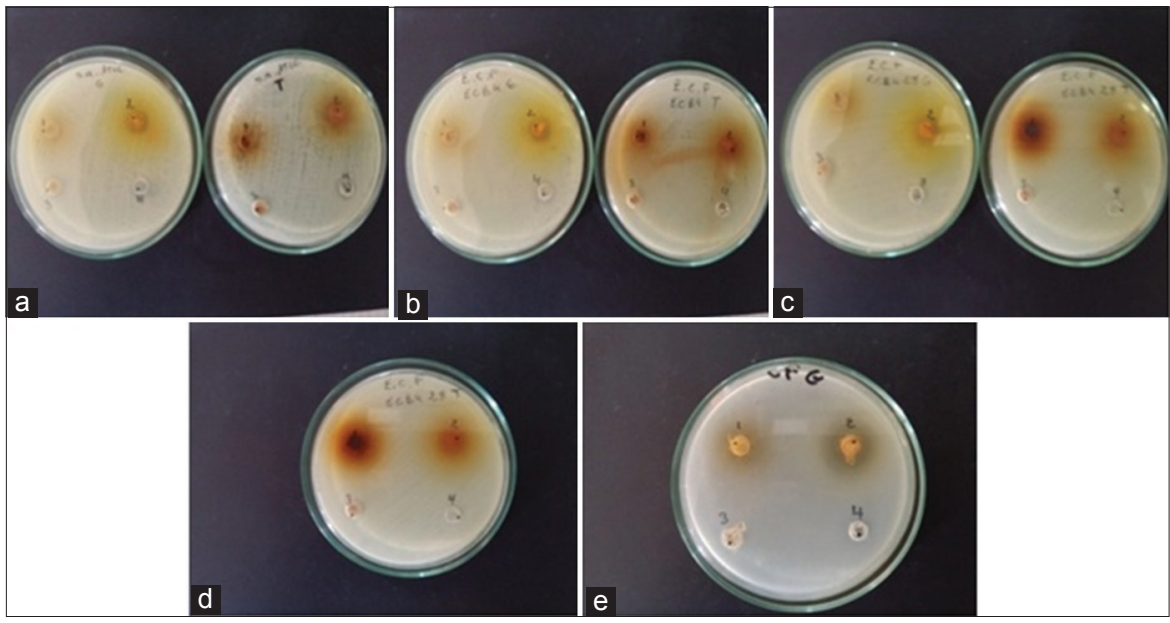

Fig. 4: Photographic illustration of the Anastatica hierochuntica macerates' well-diffusion tests against uropathogenic strains on MuellerHinton agar medium. (a): Staphylococcus aureus, (b): Escherichia coli 3, (c, d): E. coli 5, (e): Citrobacter freundii

Table 2a: Diameter values of inhibitory zones of different macerates seeds part on bacterial strains responsible for women's UGI.

\begin{tabular}{llllll}
\hline Macerates & \multicolumn{5}{l}{ Bacterial strains } \\
\cline { 2 - 6 } & E. coli 1 & E. coli 2 & E. coli 3 & E. coli 4 & E. coli 5 \\
\hline MM (mg/ml) & 6 & $13 \pm 0.72$ & 6 & $10 \pm 0.6$ & $11 \pm 0.5$ \\
235 & 6 & 6 & 6 & $7 \pm 0.5$ & 6 \\
117.5 & 6 & 6 & 6 & $7 \pm 0.5$ & 6 \\
56 & 6 & $13 \pm 0.8$ & 6 & $10 \pm 0.8$ & 6 \\
AM (mg/ml) & & $8 \pm 0.4$ & 6 & $9 \pm 0.63$ & 6 \\
190 & 6 & $7 \pm 0.3$ & 6 & $7 \pm 0.33$ & 6 \\
95 & 6 & 6 & 6 & 6 & 6 \\
45 & 6 & 6 & & & \\
EM (mg/ml) & & & 6 & & \\
100 &
\end{tabular}

UGI: Urogenital infection, E. coli: Escherichia coli, AM: Aqueous macerate, MM: Methanolic macerate, EM: Etheric macerate

(gentamicin and amikacin), phenicol (chloramphenicol), fosfomycin, and amoxicillin exhibit a good activity in our study series and in other researches [20-22] so that we must all try to preserve them.

The study of Elbouamri et al. [23] which they isolated 1472 uropathogenic Enterobacteriaceae included 924 non-repetitive of
Table 2b: Diameter values of inhibitory zones of different macerates seeds part on bacterial strains responsible for women's UGI

\begin{tabular}{|c|c|c|c|c|c|}
\hline \multirow[t]{2}{*}{ Macerates } & \multicolumn{5}{|c|}{ Bacterial strains } \\
\hline & $P . a$ & E. $f$ & P. $m$ & S. $a$ & C. $f$ \\
\hline \multicolumn{6}{|l|}{$\mathrm{MM}(\mathrm{mg} / \mathrm{ml})$} \\
\hline 235 & 6 & $12 \pm 0.85$ & $12 \pm 0.9$ & $12 \pm 0.5$ & 6 \\
\hline 117.5 & 6 & $10 \pm 0.25$ & $9 \pm 0.3$ & $10 \pm 0.4$ & 6 \\
\hline 56 & 6 & $10 \pm 0.2$ & $9 \pm 0.2$ & $9 \pm 0.33$ & 6 \\
\hline $\mathrm{AM}(\mathrm{mg} / \mathrm{ml})$ & 6 & $11 \pm 0.5$ & $11 \pm 0.53$ & $9 \pm 0.7$ & 6 \\
\hline \multicolumn{6}{|l|}{190} \\
\hline 95 & 6 & $10 \pm 0.6$ & $10 \pm 0.6$ & $8 \pm 0.15$ & 6 \\
\hline \multicolumn{6}{|l|}{45} \\
\hline EM (mg/ml) & 6 & $10 \pm 0.73$ & $10 \pm 0.34$ & $7 \pm 0.5$ & 6 \\
\hline 100 & 6 & 6 & 6 & 6 & 6 \\
\hline
\end{tabular}

Mean values of inhibition zones $(\mathrm{mm})(\mathrm{n}=3) \pm S \mathrm{~S}$. AM: Aqueous macerate,

MM: Methanolic macerate, EM: Etheric macerate, E. coli: Escherichia coli, 1, 2 3, 4, and 5: Different strains of Escherichia coli, P. a: Pseudomonas aeruginosa E. f: Enterococcus faecalis, P. m: Proteus mirabilis, S. a: Staphylococcus aureus, C. f: Citrobacter freundii. (-): no inhibition effect for a diameter of $6 \mathrm{~mm}$

E. coli strains, an overall isolation frequency of $63 \%$. The antimicrobial resistance of isolated $E$. coli strains revealed variable levels of resistance to amoxicillin, sulfamethoxazole-trimethoprim, amoxicillin+clavulanic acid, ciprofloxacin, gentamicin, nitrofuran, amikacin, and fosfomycin. 
In addition, the work of Elbakkouri et al. [24] showed a significant resistance to ampicillin and norfloxacin by the analysis of $799 \mathrm{E}$. coli uropathogenic community strains, which the consumption of antibiotics represents a risk factor favoring the evolution of these resistances.

The results of the antibacterial tests demonstrate low efficiency of the three macerates of $A$. hierochuntica L., against the tested uropathogenic strains. These results are in consistent with the work of Al-Fatimi et al. and Mohamed et al., $[25,26]$ which did not find any antibacterial activity against the same bacterial species that we tested, except for Bacillus sp. strain.

These results were also proved by the work of AlSobeai Sanad et al., [27] who tested the antimicrobial activity of ethanolic, methanolic, and aqueous extracts of $A$. hierochuntica collected from Saudi Arabia. The plant showed a variable activity against both Gram-positive and Gramnegative bacteria with inhibitory zones from 6 to $15 \mathrm{~mm}$ for Bacillus $s p$. and S. aureus and 6 to $12 \mathrm{~mm}$ for E. coli and P. aeruginosa at tested concentrations of 1,10 , and $20 \mathrm{mg} / \mathrm{ml}$.

The seed part of the studied plant seems richer in phytochemical compound than the stem part where the yield of aqueous and methanolic macerates is greater than the etheric macerate for the two vegetative parts [28]. It should also be noted that methanol can extract bioactive compounds, namely, anthocyanins, terpenoids, saponins, tannins, xanthoxylins, flavones, and polyphenols more than other solvents used [29].

The aqueous and methanolic macerates of the seeds have an average antibacterial, especially against $P$. mirabilis, E. faecalis, S. aureus, and E. coli 2, 4, and 5, while the methanolic macerate of the stems was only active on E. coli 5 strain

Several studies have highlighted the high sensitivity of Gram-positive bacteria compared to Gram-negative bacteria [30-34]. This can be attributed to the difference in the outer layers of Gram-negative and Gram-positive bacteria.

According to the work of Rahmoun et al. [35], who tested the antimicrobial activity of hydromethanolic and chloroformic extracts of A. hierochuntica, a medium activity against Acinetobacter baumannii, C. freundii, Enterobacter cloacae, E. coli, P. aeruginosa, P. mirabilis, and Salmonella typhimurium was given.

This activity is attributed to phenolic compounds which have a large spectrum of activity against Gram-negative bacteria. However, they did not show any interesting activity against Gram-positive bacteria that we have tested [28].

According to the work of Alsobeai et al. [27], the antibacterial activity against both Gram-positive and Gram-negative bacteria reveals that the plant extract contains wide -spectrum activity against various bacterial pathogens due to the presence of antimicrobial components and metabolic toxins.

The antibacterial activity of $A$. hierochuntica is probably attributed not only to the phenolic compounds grouped into several classes [28,36] but also to the alkaloids by their different physiological effects [37].

\section{CONCLUSION}

The antibacterial activities of $A$. hierochuntica $\mathrm{L}$. against some isolated bacterial strains responsible for UGI support their medicinal properties which were used as preventive or curative agent for various diseases in traditional medicine.

The antibacterial activity of methanolic and aqueous macerates of the seeds reflects the need for further investigation regarding selection and purification of bioactive compounds.

\section{ACKNOWLEDGMENTS}

We express our sincere thanks to Dr. Benchaib S. Mohamed, Head of the private Medical analysis laboratory in Bechar (Algeria), to Dr. Mohamed
DJELLOULI, Lecturer at Tahri Mohammed University of Bechar (Algeria), and also for the pedagogical laboratory of biology and chemistry team members at Tahri Mohammed University of Bechar, Algeria.

\section{AUTHOR'S CONTRIBUTION}

Collection of plant material: Snoussi MOGHTET.

Identification of the collected plant/Extraction processing: Nouria NEBBOU.

Isolation and identification of microorganisms: Dalila RAZNI.

Antibiogram, antibacterial assay, and statistical analysis: Elhassan BENYAGOUB.

Writing - original draft: Dalila RAZNI.

Writing - review and editing: Elhassan BENYAGOUB.

\section{CONFLICTS OF INTEREST}

This study represents the continuity of the work on the same plant which the phytochemical analysis was carried out first, and then, the in vitro antibacterial tests of different macerates were tested against four referenced bacterial strains responsible for food infection. In addition, the antioxidant property has been further tested. The obtained results were highly promoters as well as in the pharmaceutical or in the agrifood field. All these studies were consolidated by publications. For this purpose, the authors declare that there is no conflict of interest to disclose.

\section{REFERENCES}

1. Traxer O. Infection urinaires de l'enfant et de l'adulte, Leucocyturie. La collection Hippocrate. Institut la conférence Hippocrate; 2005. p. 1-13.

2. Foxman B. Epidemiology of urinary tract infections: Incidence, morbidity, and economic costs. Am J Med 2002;113:5-13.

3. Fihn SD. Acute uncomplicated urinary tract infection in women. N Engl J Med 2003;349:259-66.

4. Lobel B. Treatment of cystitis in women. Presse Med 1995;24:1527-9.

5. Bruneton J. Pharmacognosie, Phytochimie, Plantes Médicinales. Techniques et Documentation. $3^{\text {rd }}$ ed. Paris (Fr): Lavoisier; 1999. p. 199-204.

6. Mishra N, Behal KK. Antimicrobial activity of some spices against selected microbes. Int J Pharm Pharm Sci 2010;2:187-96.

7. Hegazy A, Kabiel H. Significance of microhabitat heterogeneity in the spatial pattern and size-class structure of Anastatica hierochuntica $\mathrm{L}$. Acta Oecol 2007;31:332-42

8. Google Maps. Collection site of Anastatica hierochuntica L in Tindouf-Algeria 2018. Available from: https://www.google.com/ maps/@29.4537111,-9.549958,6z/data=!3m1!1e3?force=lite.

9. Majhenic L, Skerget M, Knez Z. Antioxidant and antimicrobial activity of Guarana seed extracts. Food Chem 2007;104:1258-68.

10. NCCLS. Performance Standards for Antimicrobial Disk Susceptibility Tests. Approved Standard M02-A7. USA: National Committee for Clinical Laboratory Standards, Villanova. (Etats-Unis) PA.; 2002.

11. Soussy JC. Antibiotic Committee of the French Society for Microbiology; 2005.

12. Sacchetti G, Maietti S, Muzzoli M, Scaglianti M, Mansredini S, Radice M, et al. Comparative evaluation of 11 essentials oils of different origin as functional antioxydants, antiradicals and antimicrobial in food. Food Chem 2005;91:621-32.

13. Celiktas OY, Kocabas EE, Bedir E, Sucan OV, Baser KH. Antimicrobial activities of methanolic extract and essential oils of Rosmarinus officinalis, depending on location and seasonal variations. Food Chem 2007;100:553-9.

14. Vlietinck AJ, Vanden Berghe DA. Can ethnopharmacology contribute to the development of antiviral drugs? J Ethnopharmacol 1991;32:141-53

15. Eloff JN. Which extractant should be used for the screening and isolation of antimicrobial components from plants? J Ethnopharmacol 1998;60:1-8.

16. Betsy F. Epidemiology of urinary tract infections: Incidence, morbidity, and economic costs. Am J Med 2002;113:5-13

17. Benyagoub E, Benyagoub EL, Berbaoui H, Rahmani C, 
Benyoucef L. Identification and study of the emergence of antibiotic resistance of microorganisms responsible for urinary tract infections in Bechar (Algeria). Sci Lib Ed Mersenne 2013;5:1-13.

18. Adjei O, Opoku C. Urinary tract infections in African infants. Int $\mathbf{J}$ Antimicrob Agents 2004;24 Suppl 1:S32-4.

19. Aroor S, Bhaskaranand N, Kini P. Enhanced Urinalysis in Febrile Children with Suspected Urinary Tract Infection. $13^{\text {th }}$ International Congress on Infectious Diseases Abstracts; 2008.

20. Larabi K, Masmoudi A, Fendri C. Bacteriological study and resistance phenotypes of germs responsible for urinary tract infections at University hospital center in Tunis: about 1930 cases. Méd Mal Infect 2003;33:348-52.

21. Lemort M, Neuville S, Medus M, Gueudet P, Saada M, Lecaillon E. Comparative evolution of the sensitivity of Escherichia coli strains isolated from emergency room and urinary tract infections of hospitalized patients in 2002 and 2004 at the Perpignan Hospital. Pathol Biol 2006;54:426-30.

22. Muratani T, Matsumoto T. Urinary tract infection caused by fluoroquinolone- and cephem-resistant Enterobacteriaceae. Int $\mathrm{J}$ Antimicrob Agents 2006;28 Suppl 1:S10-3.

23. Elbouamri MC, Arsalane L, Kamouni Y, Bennouar N, Berraha M, Zouhair S. Current antibioticresistance profile of uropathogenic strains Escherichia coli and therapeutic consequences. Prog Urol 2014;24:1058-62.

24. Elbakkouri J, Belabbes H, Zerouali K, Belaiche A, Messaouidi D, Perrier Gros Claude JD, Elmdaghri N. Antibioticresistance of community uropathogenic Escherichia coli and antibiotic consumption in Casablanca (Morocco).Eur J Sci Res 2009;36:49-55.

25. Al-Fatimi M, Wurster M, Schröder G, Lindequist U. Antioxydant, antimicrobial and cytotoxic activities of selected medicinal plants from Yemen. J Ethnopharmacol 2007;111:657-66.

26. Mohamed AA, Khalil AA, El-Beltagi HE. Antioxidant and antimicrobial properties of kaffmaryam (Anastatica hierochuntica) and doum palm (Hyphaene thebaica). Grasas Aceites 2010;61:67-75.

27. Al Sobeai Sanad M, Abdullah AA, Mohammed SA, Joseph B,
Abdulmoneim MS. Antibacterial activity of Anastatica hierochuntica L., extracts against different groups of bacterial pathogens: An in-vitro test. Aust J Basic Appl Sci 2015;9:27-30.

28. Benyagoub E, Razni D, Moghtet S. Phytochemical composition of Anastatica hierochuntica L., can it fight the toxigenic bacterial agents responsible for food poisoning? Microbes Health 2017;6:5-8

29. Cowan MM. Plant product as antimicrobial agents. Clin Microbiol Rev 1999; $12: 564-82$

30. Falleh H, Ksouri R, Chaieb K, Karray-Bouraoui N, Trabelsi N, Boulaaba M, et al. Phenolic composition of Cynara cardunculus L. Organs, and their biological activities. C R Biol 2008;331:372-9.

31. Hayouni EA, Abedrabba M, Bouix M, Hamdi M. The effects of solvents and extraction method on the phenolic contents and biological activities in vitro of Tunisian Quercus coccifera L. and Juniperus phoenicea L. fruit extracts. Food Chem 2007;105:267-73.

32. Turkmen N, Velioglu YS, Sari F, Polat G. Effect of extraction conditions on measured total polyphenol contents and antioxidant and antibacterial activities of black tea. Molecules 2007;12:484-96

33. Shan B, Cai YZ, Brooks JD, Corke $H$. The in vitro antibacterial activity of dietary spice and medicinal herb extracts. Int J Food Microbiol 2007; 117:112-9.

34. Koné WM, Atindehou KK, Terreaux C, Hostettmann K, Traoré D, Dosso M. Traditional medicine in north Côte-d'Ivoire: Screening of 50 medicinal plants for antibacterial activity. J Ethnopharmacol 2004;93:43-9.

35. Rahmoun NM, Ziane H, Boucherit-Otmani Z. Antibacterial and antifungal screening of four medicinal plants. J Coast Life Med 2014;2:975-9.

36. Arimboor R, Kumar KS, Arumughan C. Simultaneous estimation of phenolic acids in sea buckthorn (Hippophae rhamnoides) using RPHPLC with DAD. J Pharm Biomed Anal 2008;47:31-8.

37. BerghiouaA, CheritiA, BelboukhariN, MaroufA. Ethnopharmacological and Chemical overview of Brassicaceae. Ann Univ Bechar 2009;5:1325 . 